\title{
BCL9L wt Allele
}

National Cancer Institute

\section{Source}

National Cancer Institute. BCL9L wt Allele. NCI Thesaurus. Code C132329.

Human BCL9L wild-type allele is located in the vicinity of $11 \mathrm{q} 23.3$ and is approximately 32

$\mathrm{kb}$ in length. This allele, which encodes B-cell CLL/lymphoma 9-like protein, is involved in transcriptional activation. 